\title{
Evergreen sclerophyllous Quercus forests in northwestern Yunnan, China as compared to the Mediterranean evergreen Quercus forests in California, USA and northeastern Spain
}

\author{
C. Q. Tang
}

\begin{abstract}
Tang, C. Q. 2006. Evergreen sclerophyllous Quercus forests in northwestern Yunnan, China as compared to the Mediterranean evergreen Quercus forests in California, USA and northeastern Spain. - Web Ecol. 6: 88-101.
\end{abstract}

\begin{abstract}
Evergreen sclerophyllous Quercus forests in NW Yunnan (China) were studied and compared with the Mediterranean evergreen sclerophyllous Quercus forests in central coastal California (USA) and Catalonia (NE Spain). Forests of Q. aquifolioides, Q. pannosa, Q. longispica of NW Yunnan, Q. agrifolia of California and Q. ilex of NE Spain were analyzed as representative communities. The similarities and differences at the community level in the contemporary vegetation of the sclerophyllous Quercus forest found in the three regions are clarified. The general patterns of the evergreen Quercus forest in the three regions were similar, though different assemblages of species were involved. The species diversity in all three regions was rather low. The species richness did not significantly differ among the forests, although in the Q. longispica forest it is somewhat higher than the others. The three representative species of evergreen Quercus in NW Yunnan reached the greatest maximum height, while Q. agrifolia of California had the largest basal area per ha. The $Q$. ilex forest of Spain had the lowest values for maximum tree height and dbh and the highest density per ha. Frequency of dbh size classes indicated that Q. aquifolioides, Q. pannosa, and Q. agrifolia had potentially good regeneration of the sporadic type with highest values for the intermediate size classes, and the regeneration of Q. longispica and Q. ilex was strong as indicated by a reverse-J pattern. Still, in each area, most regeneration was from sprouting. In all three regions the evergreen Quercus species have adapted to environmental changes, for instance by development of sprouting and rooting abilities to resist drought, cold conditions and various disturbances. The evergreen Quercus forests in NW Yunnan were structurally more similar to the Q. agrifolia forest of central coastal California than to the Q. ilex forest of NE Spain.
\end{abstract}

C. Q. Tang(cindytang@ynu.edu.cn), Institute of Ecology and Geobotany, Yunnan University, Kunming, 650091 China.

Evergreen sclerophyllous Quercus (sect. Suber, also Heterobalanus) forests of China are of special interest to ecologists because they exhibit exceptional environmental adaptations and harbor many endemics. Nine oak species are found in these forests (Zhou et al. 2003), distributed from Chiang Mai in northern Thailand to southwest
China and as far west as Afghanistan. These species are concentrated, however, in the Hengduan Mountains of China (Zhou 1993), and are also characteristic of western Sichuan, NW and NE Yunnan, and southeastern Tibet, where they occur from $900 \mathrm{~m}$ to $4800 \mathrm{~m}$ asl, chiefly between 2400 and $3600 \mathrm{~m}$. These oaks are morphologically 
similar to Mediterranean oaks such as Q. suber L. (cork oak) and Q. ilex L. (holm oak) (Li et al. 2000, Zhou et al. 2003), though the climates of the two regions are quite different. Three major evergreen oak species occurring in California include Q. agrifolia Nee (coast live oak), Q. wislizeni A. DC. (interior live oak) and Q. chrysolepis Liebm. (canyon live oak). Q. wislizeni form groves on inland grasslands. Q. chrysolepis is found both in canyons and on exposed slopes, often as shrubs. Q. agrifolia form a distinctive and natural community near the coast, though communities co-dominated by a combination of several Quercus species and their hybrids can also be found (Howell 1985, Hickman 1996). In Spain, Q. ilex, Q. suber, and Q. coccifera $\mathrm{L}$. are the major evergreen Quercus species. Broadleaved evergreen forests where $Q$. ilex is almost the only canopy tree species are a distinctive ecosystem of the Mediterranean Basin. In southern Spain and Portugal, the Quercus woodland overstory is composed predominantly of one or a combination of two Quercus species, Q. ilex and Q. suber. Only Q. ilex occurs in the Spanish study site, NE Spain (Rodà et al. 1999). There are many similarities between Californian and Spanish Quercus woodlands. Both are located in Mediterranean climate zones. Mediterranean-type vegetation represents an adaptive response to a hot, dry summer and mild, rainy winter conditions (di
Castri and Mooney 1973, Axelrod 1983, Moreno and Oechel 1995). Some evergreen Quercus species have radiated into very diverse environments. For instance, $Q$. aquifoiloides, Rehd. et Wils. and Q. pannosa Hand.-Mazz. range between 3000 and $4000 \mathrm{~m}$ in Yunnan, having adapted to high mountain conditions (Axelrod 1983). The evergreen sclerophyllous oaks of the Hengduan Mountain region have adapted to a hot, rainy summer and cold, dry winter climate.

Fossil records of Quercus sect Suber (Heterobalanus) date since the Miocene epoch, and this section has since become dominant in the Himalayan region ( $\mathrm{Li}$ and Guo 1976). In some regions of California, the climate of the Miocene and Pliocene periods appears to have been somewhat analogous to that of the present-day Mediterranean (Axelrod 1973). Q. ilex has been present in the Mediterranean basin at least since the Miocene (Barbero et al. 1992), where it originated far later than other sclerophyllous plants (Triat-Laval 1979, di Castri 1981, Dallman 1998). Mediterranean-type vegetation originated at about the same period of time as the east Himalayan evergreen Quercus or later (Li et al. 2000).

The genus Quercus comprises two subgenera, Quercus (with deciduous and evergreen species) and Cyclobanopsis (having only evergreen species). Fig. 1 indicates the general

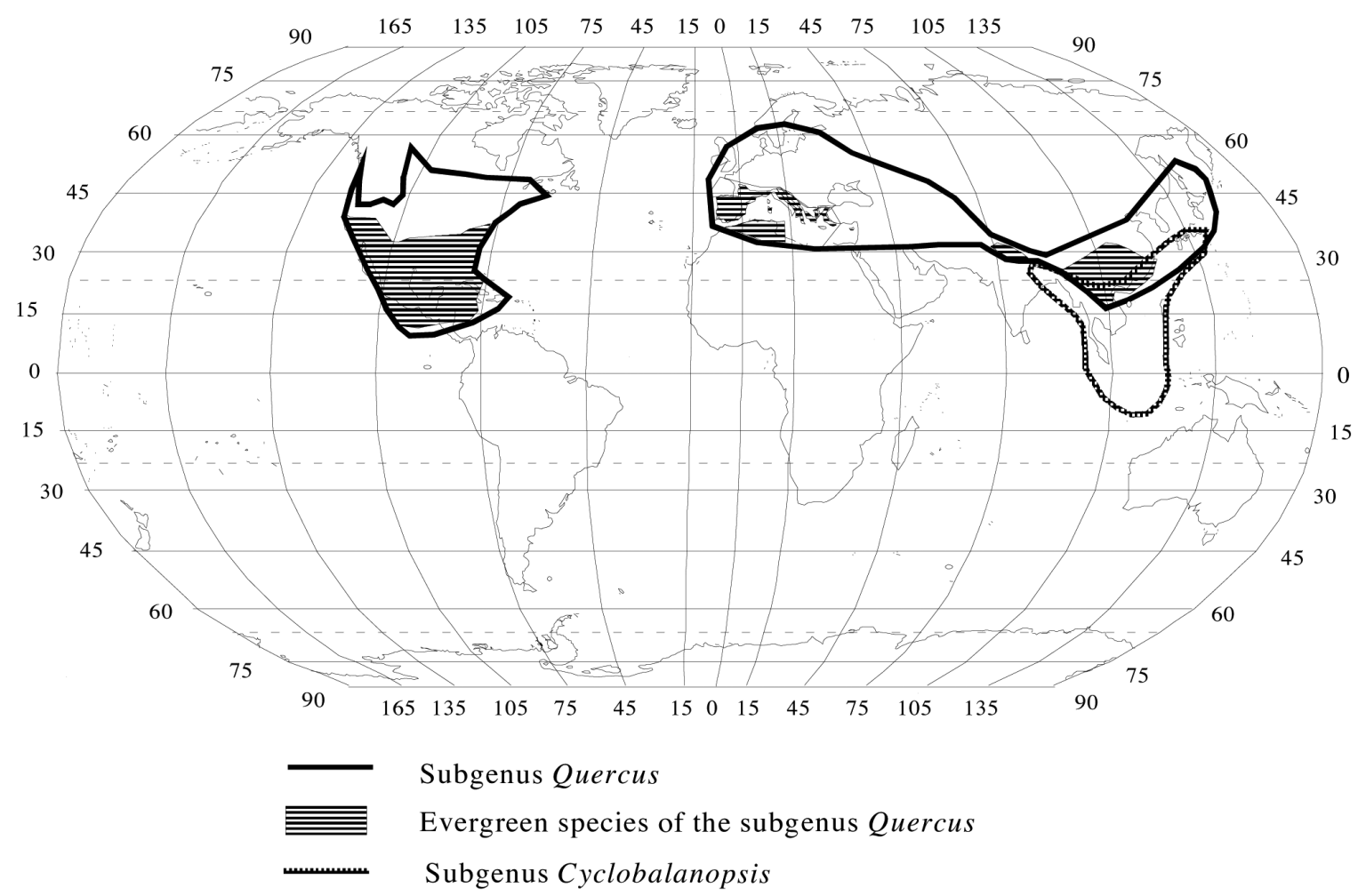

Fig. 1. General distribution of Quercus. Geographic areas of the two subgenera Quercus and Cyclobalanopsis and the evergreen species of the subgenus Quercus are indicated. Adapted from Axelrod (1983), Miller and Lamb (1985), Ohsawa et al. (1986), Burns and Honkala (1990), Clary and Tiedeman (1992), Anon. (1995), and Peterson and Boyd (1998). 
geographic distribution of the two subgenera as well as the evergreen species of the subgenus Quercus. Though some evergreen Quercus occur in Central America, in this study we only focus on NW Yunnan and Mediterranean regions. From an evolutionary point of view, Chinese evergreen sclerophyllous Quercus forest is considered to be a relic of the palaeo-Mediterranean subtropical vegetation evolved from sclerophyllous Quercus forests of the Tethys after the uplift of the Himalayas (Jing 1981, Yang 1990, Anon. 1995, Zhou 1999, Tang 2000, Sun 2002, Sun and Li 2003, Zhou et al. 2003). The purpose here is to study the similarities and differences in the contemporary vegetation of the evergreen sclerophyllous Quercus forests between NW Yunnan on the one hand, and Mediterranean regions on the other. The morphology, phylogeny and classification of the evergreen species of Chinese Quercus have been studied by Zhou (1993, 1999), Li et al. (2000), Li and Gu (2002) and Zhou et al. (2003). Zhang et al. (2005) recently examined the physiological features of $Q$. pannosa. Some large-scale floristic comparative studies between North America and Eurasia, especially on plant diversity in eastern America and eastern Asia have been conducted by Qian (1999), Ricklefs et al. (2004) and Qian et al. (2005). However, a comparative study on the woody species composition, structure and ecological adaptation to environmental conditions of evergreen Quercus forests in NW Yunnan, California and Spain has not so far been done. The aim of this paper is to clarify the similarities and differences among the evergreen sclerophyllous Quercus forests at the community level in NW Yunnan, Marin County of central coastal California, and Catalonia, NE Spain. This study contributes to a better understanding of the evergreen Quercus forests, and may provide information favoring the conservation of Yunnan evergreen Quercus forests by means of the comparison.

\section{Methods}

\section{Study areas}

The quantitative data upon which this paper is based were collected from (1) the geographic area of the Zhongdian (Shangrila) and the Deqin regions of NW Yunnan $\left(27^{\circ} 49^{\prime}-28^{\circ} 37^{\prime} \mathrm{N}, 98^{\circ} 52^{\prime}-99^{\circ} 59^{\prime} \mathrm{E}\right)$; (2) Oakwood Valley, Angel Island and the Tiburon Peninsula of Marin County, central coastal California $\left(37^{\circ} 51^{\prime}-37^{\circ} 89^{\prime} \mathrm{N}\right.$, $\left.122^{\circ} 32^{\prime}-122^{\circ} 47^{\prime} \mathrm{W}\right)$ and (3) La Castanya in the Montseny area of Catalonia, NE Spain $\left(41^{\circ} 46^{\prime} \mathrm{N}, 2^{\circ} 21^{\prime}\right.$ E). The data for NW Yunnan, except those on $Q$. aquifolioides which were adapted from Yu et al. (2003), and the data for Oakwood Valley, Angel Island and Tiburon Peninsula of California were collected by the author in May 2005 (for NW Yunnan), November 2003 (for Oakwood Valley) and November 2006 (for Angel Island and Tiburon Peninsula). Data from the Montseny area of Catalonia were adapted from Ibàñez et al. (1999), Hereter and Sánchez (1999), Terradas (1999) and Espelta et al. (1999).

The mountains of NW Yunnan are high, rugged outgrowths of the great Himalayan uplift. With steep slopes and deep chasms, the region is isolated. The most characteristic features of the area are a parallel series of mountain ranges and river valleys which derive from a system of north-south trending fault zones. Recent tectonic activity has resulted in differential uplift of fault-bounced blocks. A consequence of this is that fragments of the Tertiary surface now occur at a variety of altitudes (Liu and Zhong 1987). The region is rich in sclerophyllous plants and harbors a complex flora. Based on climatological data for the cities of Zhongdian (Shangrila) $\left(27^{\circ} 42^{\prime} \mathrm{N}, 99^{\circ} 42^{\prime} \mathrm{E}\right)$ and Deqin $\left(28^{\circ} 26^{\prime} \mathrm{N}, 99^{\circ} 11^{\prime} \mathrm{E}\right)$, average monthly temperatures range between $-3.6^{\circ} \mathrm{C}$ in December and $13.5^{\circ} \mathrm{C}$ in July for Zhongdian and between $-5.5^{\circ} \mathrm{C}$ in December and $11^{\circ} \mathrm{C}$ in June for Deqin. The mean annual precipitation is $609 \mathrm{~mm}$ for Zhongdian and $651 \mathrm{~mm}$ for Deqin (Liu et al. 1984, Jing 1992). Most of it occurs for both localities during the monsoon months of June to October. The climate in NW Yunnan is characterized by warm rainy summers and cold dry winters (Fig. 2a, b).

Oakwood Valley, located in southern Marin County in central coastal California, lies just east of the San Andreas Fault and the Pacific coast. The Tiburon Peninsula and Angel Island are situated in the south of Marin County towards San Francisco Bay ca $12 \mathrm{~km}$ to the east of Oakwood Valley. This region is characterized by very old rocks of a series known as the Franciscan Group, dating since the Jurassic period. These rocks are largely sedimentary and consist of shale, sandstones, and conglomerates, radiolarian chert with some igneous rock and serpentine (Howell 1985). The climate in Marin County is characterized by warm dry summers and cool rainy winters, similar to the climate that is found in the Mediterranean regions of southern Europe and northern Africa. Climatic data for 1961-1990 from Kentfield ( $37^{\circ} 57^{\prime}$ N, 122 $33^{\prime}$ W) near the study sites of Marin County indicate an average monthly temperatures between $8.6^{\circ} \mathrm{C}$ in January, with a precipitation as high as $264 \mathrm{~mm}$, and $19.9^{\circ} \mathrm{C}$ in July, with a scant precipitation of $3 \mathrm{~mm}$. The mean annual precipitation is $1212 \mathrm{~mm}$ (Anon. 1997) (Fig. 2c).

In Catalonia, the massifs of Montseny belong to the pre-coastal range, a chain of mid-sized mountains paralleling the Mediterranean coast, $20-30 \mathrm{~km}$ inland. The highest altitude is $1707 \mathrm{~m}$. Montseny is underlain mostly by metamorphic phyllites and schists and by granodiorites. Climatically and biogeographically, Montseny lies at the northern boundary of the Mediterranean region. At midaltitudes, where the $Q$. ilex forest is best represented, the climate is Mediterranean. At La Castanya $\left(41^{\circ} 46^{\prime} \mathrm{N}\right.$, $2^{\circ} 21^{\prime} \mathrm{E}$ ) the average monthly temperature ranges between $6^{\circ} \mathrm{C}$ in February and $21^{\circ} \mathrm{C}$ in July. The mean annual pre- 


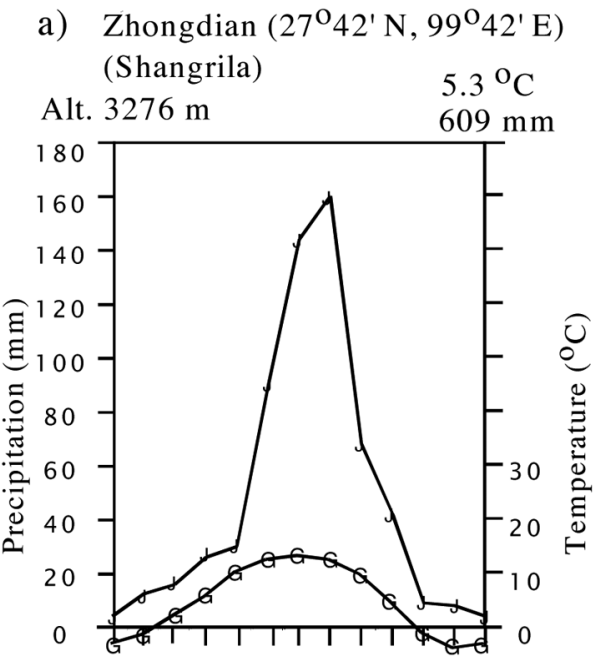

J FM A M J J A S ON D J
Precipitation $\rightarrow$

Temperature $G$

b) Deqin $\left(28^{\circ} 26^{\prime} \mathrm{N}, 9^{\circ} 11^{\prime} \mathrm{E}\right)$

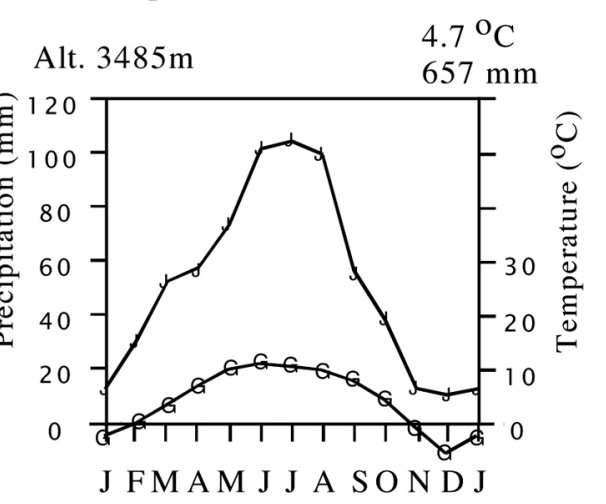

c) Kentfield $\left(37^{\circ} 57^{\prime} \mathrm{N}, 122^{\circ} 33^{\prime} \mathrm{W}\right)$

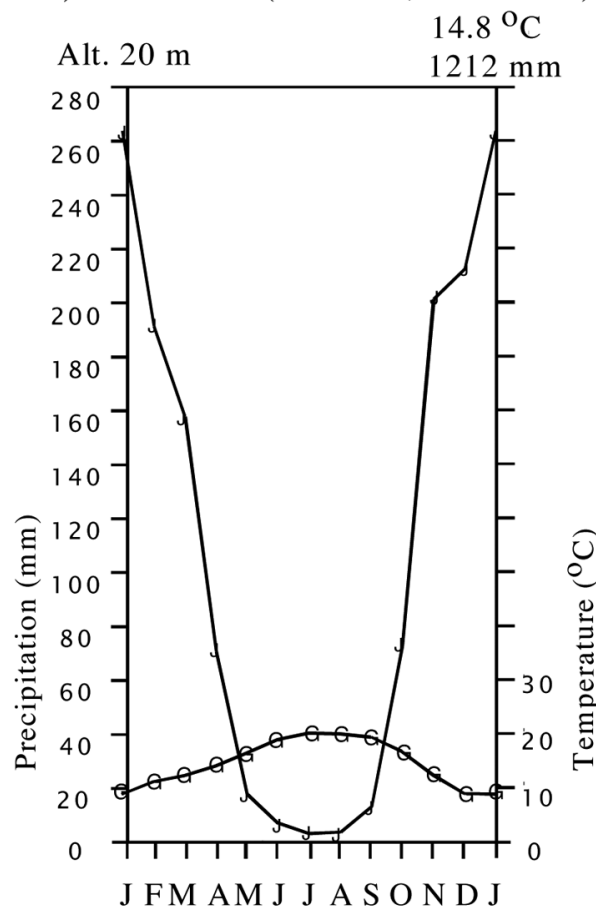

Months d) La Castanya $\left(41^{\circ} 46^{\prime} \mathrm{N}, 2^{\mathrm{O}} 21^{\prime} \mathrm{E}\right)$

$$
\begin{array}{ll} 
& 12.0^{\circ} \mathrm{C} \\
\text { Alt. } 700 \mathrm{~m} & 894 \mathrm{~mm}
\end{array}
$$

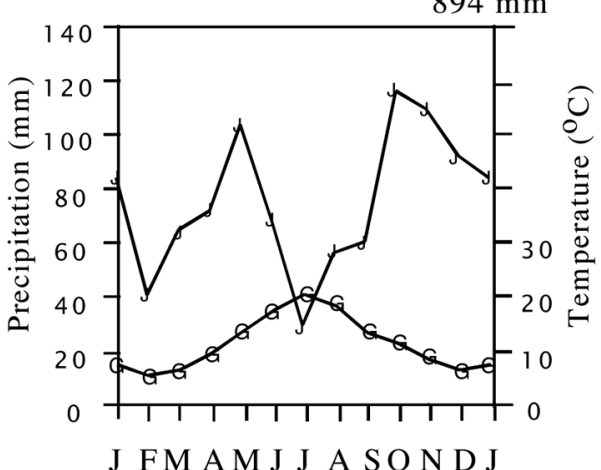

Months

Fig. 2. Climatic diagram for NW Yunnan (Zhongdian and Deqin), China, Marin (Kentfield), central coastal California, USA and La Castanya, Catalonia, NE Spain. 
cipitation is $879 \mathrm{~mm}$. Summer drought occurs, though it is attenuated by relatively high rainfall in June and by frequent storms in August and September (Hereter and Sánchez, 1999) (Fig. 2d).

\section{Data collection}

Quantitative data of vegetation were collected from a total of 16 plots $(20 \mathrm{~m} \times 20 \mathrm{~m}$ each $)$ in NW Yunnan and 10 plots (20 m $\times 20 \mathrm{~m}$ each) in Marin County, California. In Yunnan, a large number of natural hybrids, which have remained unclassified, complicated the task of sample selection. For this study we chose the Quercus species which are clearly identified in the area and form distinctive and natural communities. All plots selected met the following criteria: (1) a relatively homogeneous unit of vegetation dominated by evergreen sclerophyllous Quercus, (2) uniform topography, and (3) no evidence of disturbance by humans or other factors within the past 40 years. For this study, tree inventory was carried out for all living individuals at least $1.3 \mathrm{~m}$ tall in each plot. All were tagged with number tape, recorded with species name, tree height $(\mathrm{H})$ and diameter at breast height $(1.3 \mathrm{~m})$ i.e. dbh. As for ground vegetation, sapling and seedling individuals (height $<1.3 \mathrm{~m}$ ) in every plot were counted and their height measured. The data on Spanish study sites, derived from the literature; they were collected from 81 plots of 14 $\mathrm{m}$ diameter in the holm oak forest area of the Torrent de la Mina catchment (Ibáñez et al.1999). Tree height and dbh were measured for all living stems with a diameter $\geq 5 \mathrm{~cm}$ at $1.3 \mathrm{~m}$ height.

\section{Data analyses}

The data analyses were based on field samplings carried out by the author and on data compiled from several other sources, including Ibàñez et al. (1999), Hereter and Sánchez (1999), Terradas (1999), Espelta et al. (1999), and $\mathrm{Yu}$ et al. (2003). The relative basal area was calculated for each species (RBA, \%). For comparison of DBH class, basal area and density of Quercus species of the three regions, we took the data on trees having a diameter $\geq 5 \mathrm{~cm}$ at $1.3 \mathrm{~m}$ height for the study sites of Yunnan and California, which corresponds to the figures reported for the Spanish study site. Species richness was expressed as number of species. Diversity was calculated for each forest type using the reciprocal of the Berger-Parker index (1/d) (Magurran 1988). The Jaccard index was used to compare each of the evergreen Quercus forests in NW Yunnan to the $Q$. agrifolia forest in California and to the $Q$. ilex forest in NE Spain. I used the formula $C j=j /(a+b-j)$, where $C j$ is the Jaccard index, $a$ and $b$ are the total number of families in each of the two forests, and $j$ is the number of common families for the two forests.

\section{Results}

\section{Characteristics of the evergreen Quercus species and species composition of representative forests}

Nine major evergreen oak species occur in northern Yunnan, including $Q$. aquifolioides Rehd. et Wils., $Q$. pannosa Hand.-Mazz., Q. monimotricha Hand.-Mazz., Q. longispica (Hand.-Mazz) A. Camus, Q. guayavaefolia Levl., Q. gilliana Rehd. et Wils., Q. cocciferoides Hand.-Mazz., Q. franchetii Skan, and Q. pseudo-semecarpifolia A. Camus. We only concentrated on three species which met our sampling criteria: $Q$. aquifolioides, $Q$. pannosa and $Q$. longispica. Three major evergreen oak species occurring in California include Q. agrifolia Nee, Q. wislizeni A. DC. and $Q$. chrysolepis Liebm. However, only Q. agrifolia forms a distinctive and natural community in the study area. Quercus ilex L., Q. suber L., Q. coccifera L. are major evergreen Quercus species in Spain, but only $Q$. ilex occurs in the Spanish study site. Table 1 briefly describes the characteristics of the evergreen Quercus species of this study. Among those species, the three Chinese Quercus species occur in high altitudes $(\geq 2400 \mathrm{~m})$, and are generally taller in tree height than $Q$. agrifolia of California and $Q$. ilex of Spain. The Chinese species are shade tolerant except $Q$. aquifolioides (intolerant) and Q. pannosa (somewhat tolerant). $Q$. pannosa is mainly found in areas of limestone bedrock, while $Q$. ilex prefers calcareous soils and southern slopes. Q. aquifolioides, Q. longispica and $Q$. agrifolia are common on not too dry slopes and valley floors.

The woody species composing all Quercus forests in the three regions are shown with their relative basal area in Table 2 . The forests are named by their principal dominant species, those with the highest values of RBA. In NW Yunnan, $Q$. aquifolioides, Q. pannosa and Q. longispica were clearly the most important species, accompanied by $R h o-$ dodendron rubiginosum Franch., $R$. vernicosum Franch., $R$. oreotrephes W. W. Sm., $R$. decorum Franch., Larix potaninii Batalin, Picea likidangensis (Franch.) Pritz., Pinus densata Mast., P. amandii Franch., Populus szechuanica Schneid., Sorbus rufopilosa Schneid. and S. rehderiana Koehne. For Marin, California, Q. agrifolia was the most important species, with Umbellularia californica Hook. \& Am., Heteromeles arbutifolia (Lindley) Roemer, and Arbutus menziesii Pursh also occurring in the stands. For Montseny, Q. ilex achieved the highest level (99.4\% of RBA) of dominance, and occurred along with very small quantities of Phillyrea latifolia subsp. media L., Crataegus monogyna Jacq., Erica arborea L. and other species. In forests dominated by one evergreen species of Quercus, different assemblages of species were involved.

The vegetation on the forest floor of each of the three regions was sparse, with occurrence of some herbaceous species and climbing plants. In the study sites of NW Yun- 
Table 1. Characteristics of the studied evergreen Quercus species.

\begin{tabular}{|c|c|c|c|c|c|c|c|}
\hline Region & Species & $\begin{array}{l}\text { Height } \\
(\mathrm{m})\end{array}$ & $\begin{array}{l}\mathrm{DBH} \\
(\mathrm{cm})\end{array}$ & $\begin{array}{l}\text { Shade } \\
\text { tolerance }\end{array}$ & $\begin{array}{l}\text { Elevation } \\
(\mathrm{m})\end{array}$ & Habitats & Sources \\
\hline \multirow[t]{3}{*}{$\begin{array}{l}\text { Yunnan } \\
\text { (China) }\end{array}$} & $\begin{array}{l}\text { Quercus aquifolioides } \\
\text { Rehd. et Wils. }\end{array}$ & $\begin{array}{l}\text { Usually } \\
8-15 \text { m; } \\
\text { may } \\
\text { reach } 25 \\
\text { m; } \\
\text { shrub } \\
\text { form 3- } \\
8 \mathrm{~m}\end{array}$ & $\begin{array}{l}20-60 \mathrm{~cm} \text {; } \\
\text { may } \\
\text { reach } 100 \\
\mathrm{~cm}\end{array}$ & Intolerant & $\begin{array}{l}\text { Mainly 2400- } \\
3900 \text { m }\end{array}$ & $\begin{array}{l}\text { Sunny / semi-sunny } \\
\text { slopes; not-too dry } \\
\text { fertile slopes and } \\
\text { valley floors }\end{array}$ & $a, b, c$ \\
\hline & $\begin{array}{l}\text { Quercus pannosa } \\
\text { Hand.-Mazz. }\end{array}$ & $\begin{array}{l}\text { Usually } \\
15-20 \\
\mathrm{~m} ; \\
\text { may } \\
\text { reach } 25 \\
\mathrm{~m} ; \\
\text { shrub } \\
\text { form } 1- \\
3.5 \mathrm{~m}\end{array}$ & $\begin{array}{l}30-62 \mathrm{~cm} ; \\
\text { may } \\
\text { reach } \\
80 \mathrm{~cm}\end{array}$ & $\begin{array}{l}\text { Somewhat } \\
\text { tolerant }\end{array}$ & $\begin{array}{l}\text { Mainly 2600- } \\
3900 \mathrm{~m}\end{array}$ & $\begin{array}{l}\text { Widely distributed; } \\
\text { sunny \& semi-sunny } \\
\text { slopes; mainly in } \\
\text { areas of limestone as } \\
\text { bedrock }\end{array}$ & $\mathrm{a}, \mathrm{d}$ \\
\hline & $\begin{array}{l}\text { Quercus longispica } \\
\text { (Hand.-Mazz.) A. } \\
\text { Camus }\end{array}$ & $\begin{array}{l}\text { Usually } \\
15-20 \\
\text { m; } \\
\text { may } \\
\text { reach } 26 \\
\text { m; } \\
\text { shrub form } \\
3-8 \mathrm{~m}\end{array}$ & $\begin{array}{l}19-65 \mathrm{~cm} \\
\text { may } \\
\text { reach } 135 \\
\mathrm{~cm}\end{array}$ & Tolerant & $\begin{array}{l}\text { Mainly 2400- } \\
3400 \text { m }\end{array}$ & $\begin{array}{l}\text { Sheltered shady; } \\
\text { semi-shady, } \\
\text { Semi-sunny slopes, } \\
\text { rare on sunny slopes; } \\
\text { not too dry slopes } \\
\text { and valley floors }\end{array}$ & $\mathrm{a}, \mathrm{b}, \mathrm{d}$ \\
\hline $\begin{array}{l}\text { California } \\
\text { (USA) }\end{array}$ & Quercus agrifolia $\mathrm{Nee}$ & $\begin{array}{l}\text { Usually } \\
6-12 \mathrm{~m} \text {; } \\
\text { may } \\
\text { reach } 24 \\
\mathrm{~m}\end{array}$ & $\begin{array}{l}30-60 \mathrm{~cm} \text {; } \\
\text { may } \\
\text { reach } \\
121 \mathrm{~cm}\end{array}$ & Tolerant & $\begin{array}{l}\text { Below } 909 \mathrm{~m} \\
\text { in north, } \\
\text { up to } 1515 \mathrm{~m} \text { in } \\
\text { south }\end{array}$ & $\begin{array}{l}\text { Common on valley } \\
\text { floors and not -too- } \\
\text { dry fertile slopes }\end{array}$ & a, e \\
\hline NE Spain & Quercus ilex L. & $\begin{array}{l}\text { Usually } \\
6-12 \mathrm{~m}\end{array}$ & $10-30 \mathrm{~cm}$ & Tolerant & $\begin{array}{l}\text { Mainly 450- } \\
1200 \mathrm{~m}\end{array}$ & $\begin{array}{l}\text { Prefers calcareous } \\
\text { soils and southern } \\
\text { slopes }\end{array}$ & f, g \\
\hline
\end{tabular}

${ }^{\mathrm{a}}$ This study, ${ }_{\mathrm{b}}$ Yang (1990), ${ }^{\mathrm{d}}$ CVC (1995), ${ }^{\mathrm{f}}$ Hereter and Sánchez (1999), g Ibàñez et al. (1999), ${ }^{\mathrm{e}}$ Standiford (2002), ' Yu et al. (2003).

nan, the herbaceous species Ainsliaea latifolia (D. Don) Schultz-Bip., Thalictium finetii Boivin, Saxifraga ficicaulis Wall. Ex Sar. Cat, Leibnizia nepalensis (Kunze) Kitam., Adiantum fimbriatum Christ, and Carex ruchebraunii Franch., and the climbing plants Clematis rannunculoides Franch. and Smilax mairei Levl. were found. Usnea longissima Ach. often hang on the branches of the Quercus trees. In Marin, California, the herbaceous species Aster chilensis Nees, Dryopteris arguta (Kaulf.) Maxon, Brassica nigra (L.) Koch, Hordeum brachyantherum Nevski and occasionally climbing plants such as Marah fabaceus (Naudin) E. Greene, Hedera helix L. were found. According to Hereter and Sánchez (1999) and Terradas (1999), in Montseny,
NE Spain, herbaceous Brachypodium sylvaticum L., Melia uniflora L, Pteridium aquilinum L., Teucrium scorodonia L, climbing plants Hedera helix L., Rubus ulmifoilus Schott, Clematis flammula L., and the epiphyte Asplenium adiantum-nigrum L. were present.

\section{Woody species diversity and structural features of the forests}

Fig. 3 shows the woody species richness, the reciprocal of the Berger-Parker index (1/d) and the Jaccard index (Cj) for the evergreen Quercus forests. The mean values of 
Table 2. Floristic composition of the studied evergreen Quercus forests in NW Yunnan (China), California (USA) and Montseny (NE Spain). QAq: Quercus aquifolioides forest, QP: Q. pannosa forest, QL: Q. longispica forest, QAg: Q. agrifolia forest, QI: Q. ilex forest. $\mathrm{RBA}=$ relative basal area. $\mathrm{NA}=$ not available.

\begin{tabular}{|c|c|c|c|c|c|c|}
\hline & \multicolumn{4}{|c|}{$\begin{array}{l}\text { NW Yunnan } \\
\text { (China) }\end{array}$} & \multirow{2}{*}{$\begin{array}{l}\text { Marin } \\
\text { California } \\
\text { (USA) }\end{array}$} & \multirow{2}{*}{$\begin{array}{l}\text { La Castanya } \\
\text { Montseny } \\
\text { (Spain) }\end{array}$} \\
\hline & Forest types & QAq & $\mathrm{QP}$ & QL & & \\
\hline & Number of plots & 6 & 4 & 6 & 10 & 81 \\
\hline & Plot area $\left(\mathrm{m}^{2}\right)$ & 400 & 400 & 400 & 400 & 154 \\
\hline & Area of plots $\left(\mathrm{m}^{2}\right)$ & 2400 & 1600 & 2400 & 4000 & 12474 \\
\hline & Sites & Bitahai $^{a}$ & $\begin{array}{l}\text { Bitahai, } \\
\text { Baima- } \\
\text { xueshan }\end{array}$ & $\begin{array}{l}\text { Feilaisi, } \\
\text { Yubeng, } \\
\text { Adong }\end{array}$ & $\begin{array}{l}\text { Oakwood- } \\
\text { Valley, } \\
\text { Angel Island, } \\
\text { Tiburon } \\
\text { Peninsula }\end{array}$ & $\begin{array}{l}\text { Torrent de } \\
\text { la Mina }\end{array}$ \\
\hline & Elevation $(\mathrm{m})$ & $3500-$ & $3550-$ & $3353-$ & $55-$ & $700-$ \\
\hline & & 3900 & 3600 & 3538 & 270 & 1200 \\
\hline & & RBA & RBA & RBA & RBA & RBA \\
\hline & & $(\%)$ & $(\%)$ & $(\%)$ & $(\%)$ & $(\%)$ \\
\hline Family & Dominant species & & & & & \\
\hline \multirow[t]{6}{*}{ Fagaceae } & Quercus aquifolioides Rehd. et Wils. & 74.3 & & & & \\
\hline & Quercus pannosa Hand.-Mazz. & & 95.2 & & & \\
\hline & Quercus longispica (Hand.-Mazz.) A. Camus & & & 94.9 & & \\
\hline & Quercus agrifolia $\mathrm{Nee}$ & & & & 92.5 & \\
\hline & Quercus ilex $\mathrm{L}$. & & & & & 99.4 \\
\hline & Companion woody species & & & & & \\
\hline \multirow[t]{2}{*}{ Anacaridaceae } & Toxicodendron diversilobum E. Greene & & & & 0.002 & \\
\hline & Pistacia lentiscus L. & & & & & NA \\
\hline \multirow[t]{2}{*}{ Berberidaceae } & Berberis stiebritziana Schneid. & & & 0.01 & & \\
\hline & Berberis aquifolium Pursh & & & & 0.001 & \\
\hline \multirow[t]{2}{*}{ Betulaceae } & Betula utilis D. Don & & & 0.2 & & \\
\hline & Corylus cornuta var. californica W. Sharp & & & & 0.1 & \\
\hline \multirow[t]{3}{*}{ Caprifoliaceae } & $\begin{array}{l}\text { Lonicera hispida Pall. ex Roem. et Schult. } \\
\text { Viburnum glomoratum Maxim. subsp. }\end{array}$ & & 0.1 & 0.05 & & \\
\hline & Rotundifolium (P. S. Hsu) P. S. Hsu & & & 0.03 & & \\
\hline & Viburnum tinus $\mathrm{L}$. & & & & & NA \\
\hline \multirow[t]{10}{*}{ Ericaceae } & Rhododendron rubiginosum Franch. & 9.9 & 1.1 & & & \\
\hline & Rhododendron spiciferum Franch. & 0.2 & & & & \\
\hline & Rhododendron vernicosum Franch. & & 0.9 & & & \\
\hline & Rhododendron oreotrephes W. W. Sm. & & 0.5 & 1.4 & & \\
\hline & Rhododendron decorum Franch. & & & 0.8 & & \\
\hline & Lyonia doyonensis Hand.-Mazz. & & & 0.3 & & \\
\hline & Rhododendron yunnanensis Franch. & & & 0.2 & & \\
\hline & Arbutus menziesii Pursh & & & & 2.4 & \\
\hline & Arbutus unedo L. & & & & & NA \\
\hline & Erica arborea L. & & & & & NA \\
\hline \multirow[t]{2}{*}{ Grossulariaceae } & Ribes glaciale Wall. & & 0.01 & 0.05 & & \\
\hline & Ribes divaricatum Douglas & & & & 0.008 & \\
\hline Hydrangeaceae & Deutzia purpurascens (Franch.) Rehd. & & 0.04 & 0.03 & & \\
\hline Labiatae & Elshotzia densa Benth & & & 0.002 & & \\
\hline Lauraceae & Umbellularia californica Hook. \& Arn. & & & & 3.4 & \\
\hline Leguminosae & Caragana franchetiana Kom & & 0.02 & 0.02 & & \\
\hline Myricaceae & Myrica californica Cham. & & & & 0.03 & \\
\hline Oleaceae & Phillyrea latifolia subsp. media L. & & & & & NA \\
\hline
\end{tabular}




\begin{tabular}{|c|c|c|c|c|c|c|}
\hline & \multicolumn{4}{|c|}{$\begin{array}{l}\text { NW Yunnan } \\
\text { (China) }\end{array}$} & \multirow{2}{*}{$\begin{array}{l}\text { Marin } \\
\text { California } \\
\text { (USA) }\end{array}$} & \multirow{2}{*}{$\begin{array}{l}\text { La Castanya } \\
\begin{array}{l}\text { Montseny } \\
(\text { Spain })\end{array} \\
\text { QI }\end{array}$} \\
\hline & Forest types & $\mathrm{QAq}$ & QP & QL & & \\
\hline & Number of plots & 6 & 4 & 6 & 10 & 81 \\
\hline & Plot area $\left(\mathrm{m}^{2}\right)$ & 400 & 400 & 400 & 400 & 154 \\
\hline & Area of plots $\left(\mathrm{m}^{2}\right)$ & 2400 & 1600 & 2400 & 4000 & 12474 \\
\hline & Sites & Bitahai $^{a}$ & $\begin{array}{l}\text { Bitahai, } \\
\text { Baima- } \\
\text { xueshan }\end{array}$ & $\begin{array}{l}\text { Feilaisi, } \\
\text { Yubeng, } \\
\text { Adong }\end{array}$ & $\begin{array}{l}\text { Oakwood- } \\
\text { Valley, } \\
\text { Angel Island, } \\
\text { Tiburon } \\
\text { Peninsula }\end{array}$ & $\begin{array}{l}\text { Torrent de } \\
\text { la Mina }{ }^{b}\end{array}$ \\
\hline & Elevation (m) & $3500-$ & $3550-$ & $3353-$ & $55-$ & $700-$ \\
\hline & & 3900 & 3600 & 3538 & 270 & 1200 \\
\hline & & RBA & RBA & RBA & RBA & RBA \\
\hline & & $(\%)$ & $(\%)$ & $(\%)$ & $(\%)$ & $(\%)$ \\
\hline \multirow[t]{6}{*}{ Pinaceae } & Larix potaninii Batalin & 8 & & & & \\
\hline & Picea likidangensis (Franch.) Pritz. & 5.9 & 0.8 & 0.19 & & \\
\hline & Abies georgei var. Smithii & 0.7 & & 0.09 & & \\
\hline & (Viguie et Gaussen) Cheng et L. G. Fu & & & & & \\
\hline & Pinus densata Mast. & & & 0.8 & & \\
\hline & Pinus amandii Franch. & & 0.8 & & & \\
\hline \multirow[t]{2}{*}{ Rhamnaceae } & Berchmia yunnanensis Franch. & & & 0.02 & & \\
\hline & Rhamnus alaternus L. & & & & & NA \\
\hline \multirow[t]{7}{*}{ Rosaceae } & Sorbus rufopilosa Schneid. & 1 & & & & \\
\hline & Sorbus rehderiana Koehne & & 0.4 & & & \\
\hline & Rosa sweginzowii Rolfe & & 0.03 & & & \\
\hline & Dichotomanthes tristaniaecarpa Kurz & & 0.03 & 0.04 & & \\
\hline & Cotoneaster franchetii Boiss & & & 0.04 & 0.05 & \\
\hline & Heteromeles arbutifolia (Lindley) M. Roemer & & & & 1.5 & \\
\hline & Crataegus monogyna Jacq. & & & & & NA \\
\hline Salicaceae & Populus szechuanica Schneid. & & & 0.8 & & \\
\hline
\end{tabular}

${ }^{a}$ Data on Quercus aquifolioides forest in Bitahai are from Yu et al. (2003).

b Data on Quercus ilex forest in Torrent de la Mina are from Hereter \& Sánchez (1999), Ibàñez et al. (1999) and Terradas (1999).

woody species richness were low (7 to 11 species) (Fig. 3a). Only Q. longispica communities (11 species) were significantly higher than the others. The low reciprocal of the Berger-Parker indices (1.01 to 1.33) shows the high dominance concentration and low diversity in all forest communities. Q. aquifolioides had a value higher (1.33) than the others. The Jaccard indices indicate that the similarities at the family level of Yunnan Quercus forests, as compared to Q. agrifolia of California and to Q. ilex of NE Spain, did not differ significantly by ANOVA except for $Q$. pannosa (Fig. 3c).

The maximum tree height of the three Yunnan species, Q. aquifolioides, Q. pannosa and Q. longispica, was over 20 $\mathrm{m}$, whereas Q. agrifolia in California and Q. ilex in NW Spain reached just $17 \mathrm{~m}$ and $12 \mathrm{~m}$, respectively (Fig. 4a). The maximum dbh was $57 \mathrm{~cm}$ for Q. aquifolioides and 62 $\mathrm{cm}$ for Q. pannosa. Q. longispica and Q. agrifolia reached $82 \mathrm{~cm}$ and $79 \mathrm{~cm}$, respectively. Q. ilex had only $30 \mathrm{~cm}$ of dbh (Fig. 4b). The basal area of $46.3 \mathrm{~m}^{2} \mathrm{ha}^{-1}$ for Q. agrifo- lia was the highest, while those for Q. pannosa, Q. longispica and Q. ilex were low $\left(<20 \mathrm{~m}^{2} \mathrm{ha}^{-1}\right)$ (Fig. 4c). Q. ilex had the highest density of 1911 stems ha $^{-1}$, whereas $Q$. pannosa showed the lowest density with 918.8 stems ha ${ }^{-1}$ (Fig. 4d). Though the ages of the study forests differ among the three regions, the structural features of the forests represent the oldest, most natural Quercus communities of their respective local regions. According to historical events as seen records of cutting and livestock grazing, the Q. agrifolia forest of California is at an age of c. 60-80 yr, the Q. ilex forest of NE Spain at an age of ca 30-50 yr. The Q. aquifolioides and Q. pannosa might be 60-75 yr old, and Q. longispica 60-90 yr old.

\section{Size distribution of population}

The evergreen species of Quercus in the three regions include sporadic and inverse-J types of frequency of size dis- 
a)

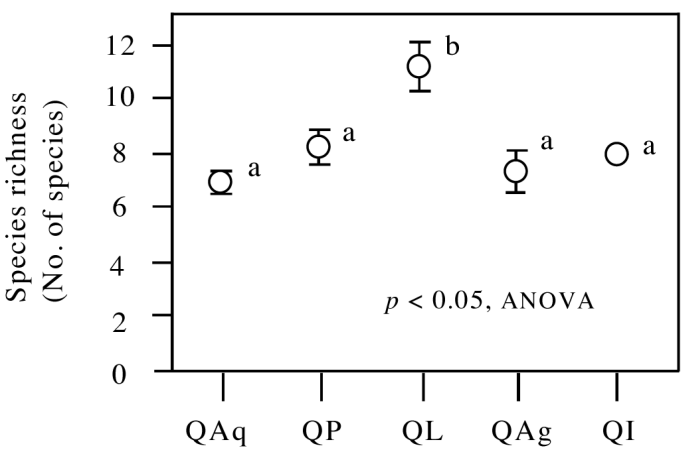

b)

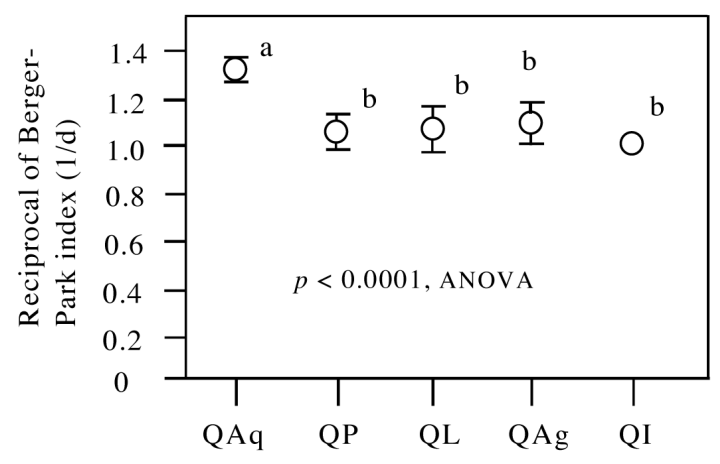

c)

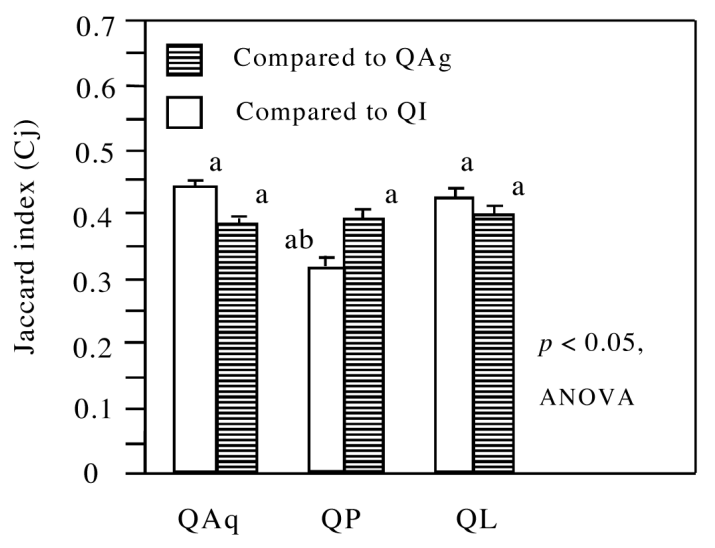

Forest types

Fig. 3. a) Species richness (mean $\pm S E$ ) and b) the reciprocal of Berger-Park index (1/d) (mean \pm SE) for the five evergreen Quercus forests of NW Yunnan, California and NE Spain. c) Jaccard index $(\mathrm{Cj})$ (mean $\pm \mathrm{SE}$ ) for the evergreen Quercus forests in NW Yunnan as compared to the Q. agrifolia forest in California and the $Q$. ilex forest in NE Spain at the family level. Significantly different values are indicated by different letters. Forests sharing the same letters do not differ significantly by ANOVA, $p<0.05$ for a), $p<0.001$ for b), $p<0.05$ for c). QAq: Quercus aguifolioides forest; QP: Q. pannosa forest; QL: Q. longispica forest; QAg: $Q$. agrifolia forest; QI: Q. ilex forest. tribution (Fig. 5). The sporadic type, with highest values for the intermediate size classes, indicates the possibility of good regeneration. Q. pannosa and $Q$. aquifolioides in Yunnan and Q. agrifolia in California were of the sporadic type. We found some seedlings and saplings for the first species, but only a few for the two others. Muick and Bartolome (1987), Standiford et al. (1991) and Barrett (1995) have reported that the natural regeneration of oaks in California is not good. The inverse-J type, having the highest frequency in small dbh classes with a gradual decrease in the number of individuals towards the large sizeclasses, suggests that regeneration is active. Q. longispica in Yunnan and Q. ilex in Spain were of the inverse-J type. We found some seedlings and a few saplings of $Q$. longispica on not too dry slopes in Adong, Deqin, Yunnan. Most present holm oak $(Q$. ilex) stands in the western Mediterranean basin were favored by man in early historic times, and $Q$. ilex forests have been managed over many centuries. The forests in Montseny were intensively coppiced for charcoal production until the 1950s (Canadell et al. 1999). They may be considered structurally as coppices (Ibànez et al 1999). It is impossible to find a more natural forest in Spain comparable to the coppices. The difficulties encountered by $Q$. ilex seedlings in establishing themselves have been reported by Retana et al. (1999).

\section{Sprouting ability}

The ratio of sprouts to main stems for the five evergreen species of Quercus in the three regions is shown in Fig. 6. $Q$. ilex reached the highest ratio at 4.7 , followed by $Q$. longispica (0.94), Q. agrifolia (0.8), Q. pannosa (0.47), and $Q$. aquifolioides (0.35). The ratios were for non-coppice Quercus forests, except that for $Q$. ilex, the only data available, were recorded $30 \mathrm{yr}$ after thinning. Sprouting accounts for most of the regeneration in these forests. According to the author's field observation in both NW Yunnan and Marin, California, the sprouts originate above or below ground level. For Q. pannosa and Q. longispica, sprouting was also observed occurring in seedlings and saplings. On the basis of our field survey, the ratio of sprouts to main stems reached 4.4 in the coppices of $Q$. longispica in NW Yunnan (datum not shown in Fig. 6). This is similar to $Q$. ilex, which resprouts more vigorously after being cut.

\section{Discussion}

\section{Adaptation to changing environments}

The evergreen oaks of NW Yunnan have adapted to environmental conditions by means of xerophytic characteristics such as dense hairs, thick cuticles, lignified epidermal 
a)

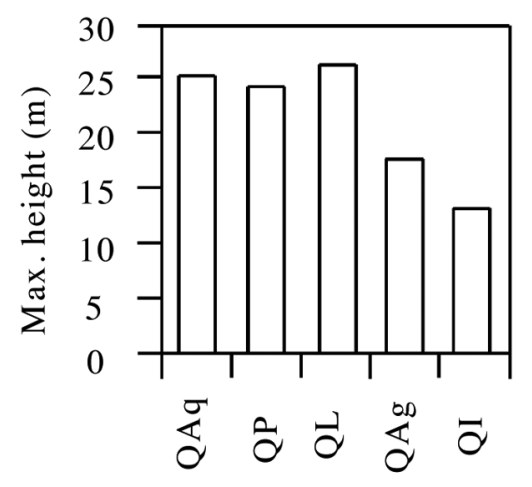

c)

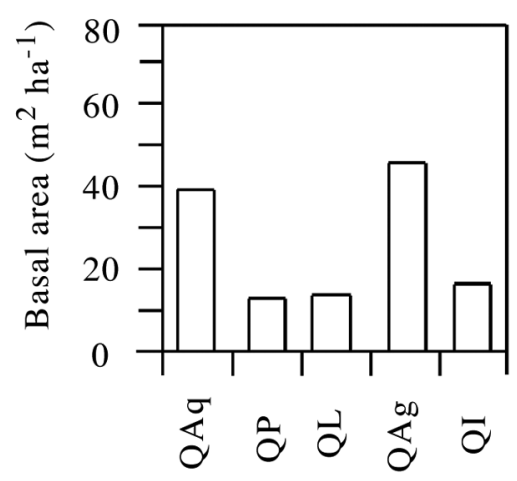

Evergreen Quercus species b)

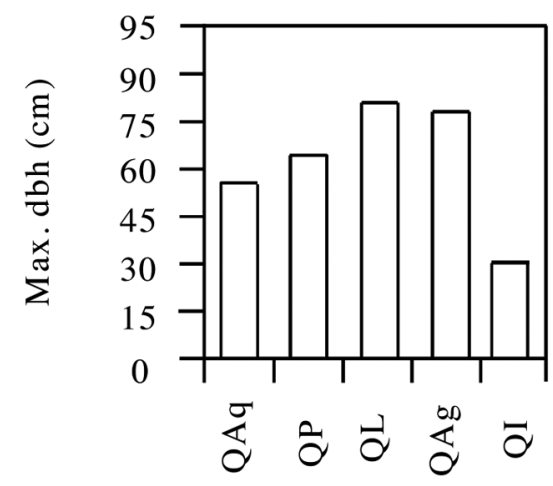

d)

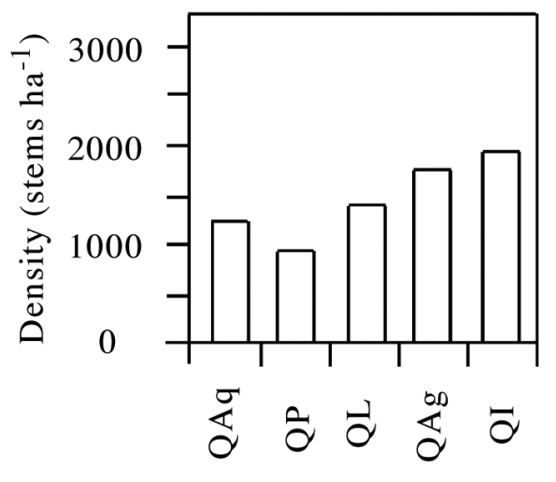

Evergreen Quercus species

Fig. 4. Structural features of the evergreen sclerophyllous Quercus forests. QAq: Quercus aquifolioides, QP: Q. pannosa, QL: Q. longispica; QAg: Q. agrifolia; QI: Q. ilex.

cell walls and cuticles and low stomatal density (Zhou et al. 2003). Moreover, their sprouting ability is high. Some sprouts were found from Quercus seedlings of the Yunnan area and California. A sign of this ability is a sprout's higher capacity to form adventitious roots in comparison with cuttings taken from shoots in the crown of the same tree. Sprouting in seedlings promotes their survival under a variety of stressful conditions, including suppression by canopy trees, herbivory, site exposure, pathogens and desiccation. Although sprouting is more conspicuous in mature trees than in seedlings, it is less significant ecologically (del Tredici 2001). Q. ilex resprouts vigorously after disturbances, with sprouts occurring by activation of dormant buds located on the stump, the root crown or - to a lesser extent - the roots (Giovannini et al. 1992, Retana et al. 1992, Sardans et al. 2004, Broncano et al. 2005). The five studied Quercus species generally have strong sprouting ability and are able to resprouts even more vigorously after disturbances.

Development of deep roots is thought to be one of the mechanisms for surviving summer drought. In California,
Stone and Kalisz (1991) and Canadell et al. (1996) reported that rooting depth of Q. agrifolia reached $10.7 \mathrm{~m}$. Data on rooting depth for evergreen Quercus of NW Yunnan are not available, though all the species were observed by the author on sites with deep soils as well as very shallow, rocky soils.

According to Zhang et al. (2005), the optimum photosynthetic temperature $\left(\mathrm{T}_{\text {opp }}\right)$ of $Q$. pannosa was significantly lower than those for Mediterranean oaks. This species could adapt well to low but not to high temperatures, which indicated that cold-tolerance would be an important determinant of the distribution of this oak in the NW Yunnan area.

\section{Sustainability}

The poor natural regeneration found in some oak species may be due to damage to seed by insects and vertebrates (Herrera 1995, Fukumoto and Kajimura 2001). This is the case of the holm oak forests in NE Spain, where a large 


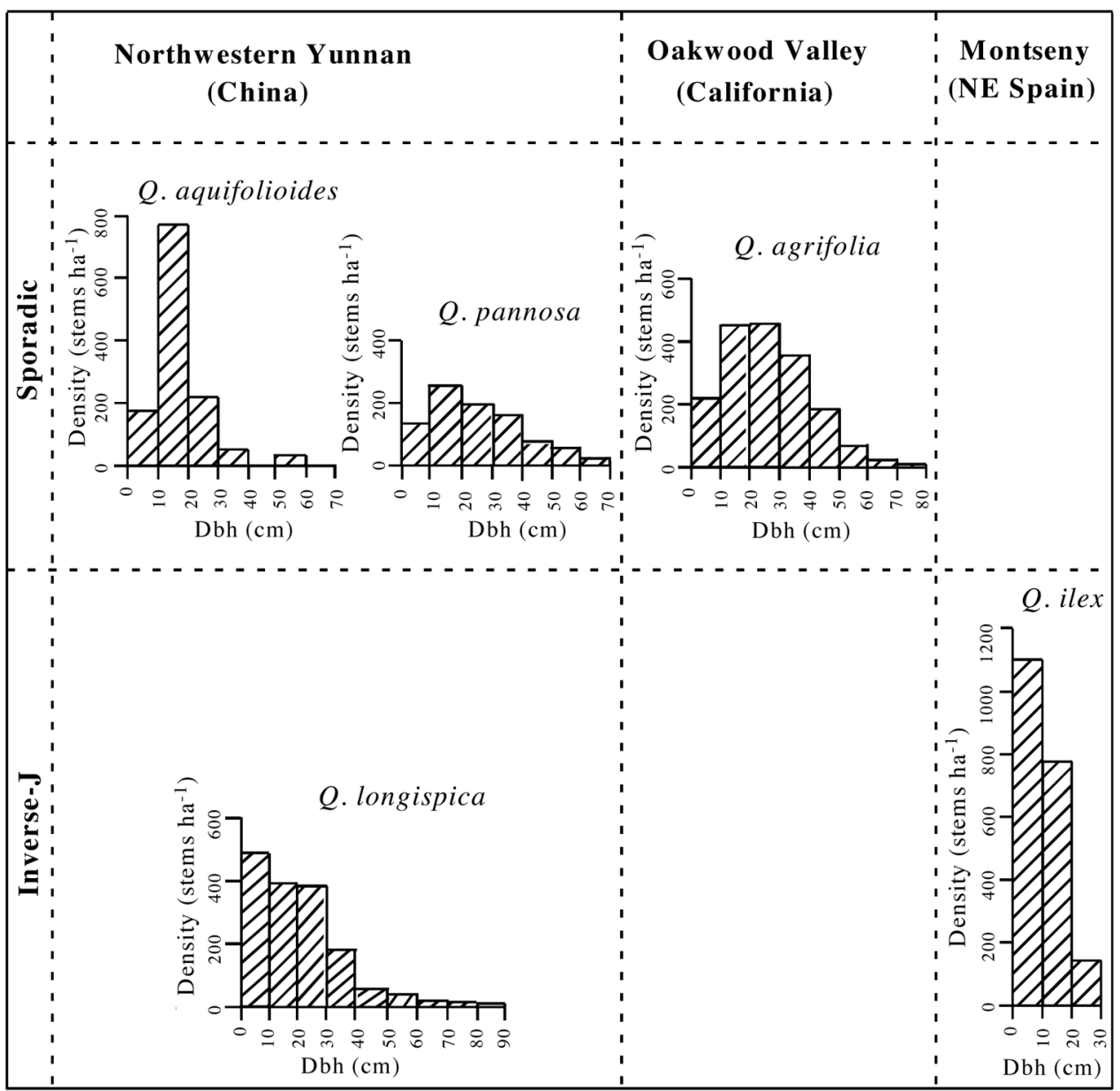

Fig. 5. Frequency of dbh size-classes of the studied evergreen sclerophyllous Quercus species.

number of animals can consume acorns, decreasing the probabilities of seedling success (Siscart et al. 1999). But the opposite result can arise from seed dispersal by animals, on which the regeneration of some oak species is strongly dependent (Borchert et al. 1989, Chambers and Macmahon 1994, Jensen et al. 2004). Ongoing monitoring on the sites should contribute to a more comprehensive understanding of the regeneration and survival of these Quercus species. Moreover, the healthy survival of evergreen sclerophyllous Quercus forests in NW Yunnan is threatened by firewood production and livestock rising. Most of the evergreen Quercus forests have been turned into coppice and scrub communities by human activities. Some cutting stumps in relatively natural forests were still found in NW Yunnan. Fire is another threat in Yunnan. Periodic fire is a natural event in California (Moreno and Oechel 1994). A new and serious threat is sudden oak death caused by the pathogen Phytophthora ramorum, which is killing trees, particularly coast live oaks $(Q$. agrifolia) in the Coastal Range of California (McPherson et al. 2005). In the Mediterranean basin, holm oak ( $Q$. ilex) forests have long been severely and continuously modified by wood cutting (coppicing for firewood or charcoal production), repeated fires, and grazing by sheep and goats (Barbero et al. 1992, Cierjacks and Hensen 2004). In Spain, the holm oak $(Q$. ilex) forests bear the imprint of past cultivation or coppicing, and their present structure, often characterized by high-density stands of stump sprouts, is likely to be replaced over time by other vegetation owing to abandonment or shift in forest management (Rodà et al. 1999).

\section{Conclusion}

The data presented herein show the similarities as well as the differences between the evergreen sclerophyllous Quercus forests of Yunnan, China and those of the Mediterranean climates of Marin County, California, USA and Montseny, NE Spain. Although the climate in NW 


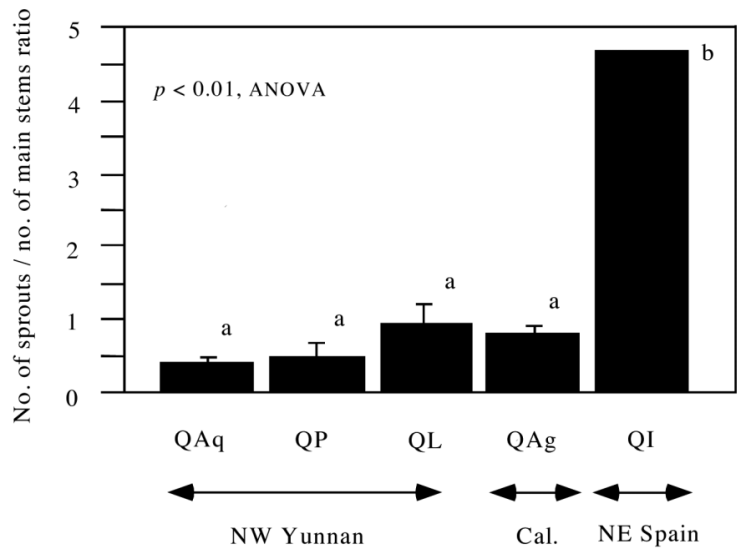

Fig. 6. Ratios (mean $\pm S E$ ) of the number of sprouts to the number of main stems for each evergreen sclerophyllous Quercus species. QAq: Quercus aquifolioides, QP: Q. pannosa, QL: Q. longispica, QAg: Q. agrifolia, QI: Q. ilex. Cal.: California. Significantly different values $(\mathrm{p}<0.01)$ are indicated by different letters. Species sharing the same letters do not differ significantly by ANOVA.

Yunnan is characterized by warm rainy summers and cold dry winters, the reverse of the hot dry summers and cool rainy winters of the Mediterranean-type climate in California and Spain, and in spite of the long distances separating the communities, the general patterns of the evergreen Quercus forest vegetation are similar. These general patterns are defined by a similar high dominance concentration and low species diversity according to the reciprocal Berger-Park index $(1 / d)$, sparse ground vegetation with herbaceous species and climbing plants, and a poor seedling establishment that is counteracted by sprouting. Different assemblages of species are involved in the three regions. However, the forests in NW Yunnan share species of the common families Ericaceae, Rosaceae, Betulaceae, Grossulariaceae and Berberidaceae with the California forest, and of Ericaceae, Caprifoliaceae, Rhamnaceae and Rosaceae with the forest in NE Spain. The evergreen Quercus forests of NW Yunnan are structurally more similar to the Q. agrifolia forest of California than to the $Q$. ilex forest in NE Spain. This may be due to the long historic human influence on the Spanish forest. In contrast, the evergreen Quercus forests in NW Yunnan and California are relatively natural. The Chinese evergreen Quercus forests are thus precious remnants of a once widespread forest type which today is threatened wherever it survives. As part of the effort to prevent further environmental degradation, science-based management of the forests and restrictions on their use to provide firewood and food for farm animals should be high priorities.

Acknowledgements - Thanks to Ms. Shengjing Peng and Mr. Zhenhua Sun for field assistance. This study was supported by a grant from the China National Key Basic Research Program 2003 CB415102.

\section{References}

Anonymous. 1995. The vegetation of China (in Chinese). The Committee on the Vegetation of China. - Science Press.

Anonymous. 1997. Climatological data, California 101(01). The National Oceanic and Atmospheric Administration, National Climatic Data Center.

Axelrod, D. I. 1973. History of the Mediterranean ecosystem in California. - In: di Castri, F. and Mooney, H. A. (eds.), Mediterranean-type ecosystem, origin and structure. Ecological studies 7. - Springer-Verlag, pp. 225-277.

Axelrod, D. I. 1983. Biogeography of oaks in the Arcto-Tertiary Province. - Ann. Missouri Bot. Gard. 70: 629-657.

Barbero, M., Loisel, R. and Quèzel, P. 1992. Biogeography, ecology and history of Mediterranean Quercus ilex L. ecosystem. - Vegetatio 99/100: 19-34.

Barrett, J. W. (ed.). 1995. Regional silviculture of the United States. $3^{\text {rd }}$ ed. - John Wiley and Sons.

Borchert, M.I., Davis, F.W., Michaelsen, J. and Oyler, L.D. 1989. Interaction of factors affecting seedling recruitment of blue oak (Quercus douglasii) in California. - Ecology 70: 389-404.

Broncano, M. J., Retana, J. and Rodrigo, A. 2005. Predicting the recovery of Pinus halepensis and Quercus ilex forests after a large wildfire in NE Spain. - Plant Ecol. 180: 47-56.

Burns, R. M. and Honkala, B. H., (tech. coords.). 1990. Silvics of North America: 1. Conifers; 2. Hardwoods. - Agriculture Handbook 654, U.S. Department of Agriculture, Forest Service, Washington D.C.

Canadell, J., Jackson, R. B., Ehleringer, J. R et al. 1996. Maximum rooting depth of vegetation types at the global scale. Oecol. 108: 583-595.

Canadell, J., Djema, A., López, B.et al. 1999. Structure and dynamics of the root systems. - In: Rodà, F., Retana, J., Gracia, C. A. and Bellot, J. (eds.), Ecology of Mediterranean evergreen oak forests. - Springer, pp. 89-103.

Chambers, J. C. and Macmahon, J. A. 1994. A day in the life of a seed: movements and fates of seeds and their implications for natural and managed systems. - Ann. Rev. Ecol. Syst. 25: 263-292.

Cierjacks, A. and Hensen, I. 2004. Variation of stand structure and regeneration of Mediterranean holm oak along a grazing intensity gradient. - Plant Ecol. 173: 215-223.

Dallman, P. R. 1998. Plant life in the Mediterranean climates. Oxford Univ. Press.

del Tredici, P. 2001. Sprouting in temperate trees: a morphological and ecological review. - Bot. Rev. 67: 121-140.

di Castri, F. 1981. Mediterranean-type shrublands of the world. In: di Castri, F., Goodall, D. W. and Specht, R. L. (eds.), Mediterranean-type shrublands: ecosystems of the world 11. - Elsevier, pp. 1-52.

di Castri, F. and Mooney, H. A. (eds.). 1973. Mediterranean-type ecosystems, origin and structure. - Springer-Verlag.

Espelta, J. M., Sabaté, S. and Retana, J. 1999. Resprouting dynamics. - In: Rodà, F., Retana, J., Gracia, C. A. and Bellot, J. (eds.), Ecology of Mediterranean evergreen oak forests. Springer, pp. 61-73. 
Fukumoto, H. and Kajimura, H. 2001. Guild structure of seed insects in relation to acorn development in two oak species. Ecol. Res. 16: 145-155.

Giovannini, G., Perulli, D., Piussi, P. et al. 1992. Ecology of vegetative regeneration after coppicing in macchia stands in central Italy. - Vegetatio 99/100: 331-343.

Glary, W. P. and Tiedemann, A. R. 1992. Ecology and values of Gamble Oak woodlands. - In: Ffolliott, P. F., Gottfried, G. J., Bennett, D. A., Hernandez C., V. M., Ortega-Rubio, A. and Hamre, R. H. (tech. coord.), Ecology and management of oak and associated woodlands: perspectives in the southwestern United States and northern Mexico. U.S. Forest Service General Technical Report RM-218. - Rocky Mountain Forest and Range Experiment Station, pp. 7895.

Hereter, A. and Sánchez, J. R. 1999. Experimental areas of Prades and Montseny. - In: Rodà, F., Retana, J., Gracia, C. A. and Bellot, J. (eds.). Ecology of Mediterranean evergreen oak forests. - Springer, pp. 15-27.

Herrera, J. 1995. Acorn predation and seedling production in a low-density population of cork oak (Quercus suber L.). - For. Ecol. Manage. 76: 197-201.

Hickman, J. C. (ed.) 1996. The Jepson Manual, higher plants of California. - Univ. of California Press.

Howell, J. T. 1985. Marin flora. Manual of the flowering plants and ferns of Marin County, California. - Univ. of California Press.

Ibàñez, J. J., Liedó, M. J., Sánchez J. R. et al. 1999. Stand structure, aboveground biomass and production. - In: Rodà, F., Retana, J., Gracia, C. A. and Bellot, J. (eds.), Ecology of Mediterranean evergreen oak forests. - Springer, pp. 31-45.

Jing, Z. Z. 1981. A mossy forest appearing in the sclerophyllous evergreen broad-leaf forests-Quercetum pannosum nimborum (in Chinese with English abstract). - Acta Bot. Yunnanica 3: 75-88.

Jing, Z. Z. 1992. The natural vegetation types of Yunnan, China. - In: Proceedings of the international symposium, Beijing, September 1986. Braun-Blanquetia, a series of geobotanical monographs 8: mountain vegetation. - Tipografia "La Nuova Stampa", pp. 65-76.

Li, H. and Guo, S. 1976. Miocene flora of Nanmulin in Tibet (in Chinese with English abstract). - Acta Palaeobot. Sin. 15: 598-609.

Li, J. Q., Guo, Y. S. and Romane, F. 2000 Environmental heterogeneity and population variability of sclerophyllous oaks (Quercus Sec. suber) in East Himalayan Region. - Forestry Stud. China 2: 1-15.

Li, W. Y. and Gu., W. C. 2002. Advance in genetic diversity in oaks. - World For. Res. 15: 42-49.

Liu, L. H., Yu, Y. D. and Zhang, J. H. 1984. The division of vertical vegetation zones in Hengduanshan (in Chinese with English abstract). - Acta Bot. Yunnanica 6: 205-216.

Liu, S. Z. and Zhong, X. H. 1987. The geomorphology of Hengduan Mountains, China. - Int. Geomorphology Proc. $1^{\text {st }}$ conference, vol. 2, pp. 229-237.

Magurran, A. E. 1988. Ecological diversity and its measurement. - Princeton Univ. Press.

McPherson, B. A., Mori, S. R., Wood, D. L. et al. 2005. Sudden oak death in California: Disease progression in oaks and tanoaks. - For. Ecol. Manage. 213: 71-89.

Miller, H. A. and Lamb, S. H. 1985. Oaks of North America. Naturegraph Publishers, Happy Camp, CA.
Moreno, J. M. and Oechel, W. C. (eds.). 1994. The role of fire in Mediterranean-type ecosystems. Ecological studies 107. Springer-Verlag.

Moreno, J. M. and Oechel, W. C. (eds.). 1995. Global change and Mediterranean-type ecosystems. - Springer-Verlag.

Muick, P. C. and Bartolome, R. 1987. An assessment of natural regeneration of oaks in California. - Report submitted to the Forest and Rangeland Assessment Program, California Department of Forestry and Fires Protection, Sacramento.

Ohsawa, M., Shakya, P. R. and Numata, M. 1986. Distribution and succession of west Himalayan forest types in the eastern part of the Nepal Himalaya. - Mount. Res. Devel. 6: 143157.

Peterson, R. S. and Boyd, C. S. 1998. Ecology and management of sand shinnery communities: a literature review U.S. Forest Service General Technical Report RMRS-GRT-16. - Rocky Mount. Res. Station.

Qian, H. 1999. Spatial pattern of vascular plant diversity in North America North of Mexico and its floristic relationship with Eurasia. - Ann. Bot. 83: 271-283.

Qian, H., Ricklefs, R. E. and White, P. S. 2005. Beta diversity of angiosperms in temperate floras of eastern Asia and eastern North America. - Ecol. Letters 8: 15-22.

Retana, J., Riba, M., Castell, C. et al. 1992. Regeneration by sprouting of holm oak (Quercus ilex L.) stands exploited by selection thinning. - Vegetatio 99/100: 355-364.

Retana, J., Espelta, J. M., Gracia, M. et al. 1999. Seedling recruitment. - In: Rodà, F., Retana, J., Gracia, C. A. et al. (eds.), Ecology of Mediterranean evergreen oak forests. - Springer, pp. 89-103.

Ricklefs, R. E., Qian, H. and White, P. S. 2004. The region effect on mesoscale plant species richness between eastern Asia and eastern North America. - Ecography 27: 129-136.

Rodà, F., Retana, J., Gracia, C. A. et al. (eds.). 1999. Ecology of Mediterranean evergreen oak forests. - Springer.

Sardans, J., Rodà, F. and Peñuelas, J. 2004. Phosphorous limitation and comparative capacities of Pinus halepensis and Quercus ilex subsp rotundifolia on different soils. - Plant Ecol. 174: 305-317.

Siscart, D., Diego, V. and Lioret, F. 1999. Acorn Ecology. - In: Rodà, F., Retana, J., Gracia, C. A. and Bellot, J. (eds.), Ecology of Mediterranean evergreen oak forests. - Springer, pp. 75-87.

Standiford, R. B., McDoughald, N. K., Phillips, R. and Nelson, A. 1991. South sierra oak regeneration survey. - Cal. Agr. 45: $12-14$.

Stone, E. L. and Kalisz, P. J. 1991. On the maximum extent of tree roots. - For. Ecol. Manage. 46: 59-102.

Sun, H. 2002. Tethys retreat. Himalaya and Hengduan Mountains and its significance for the origin and development of Sino-Himalayan elements and alpine flora (in Chinese with English abstract). - Acta Bot. Yunnanica 24: 273-288.

Sun, H. and Li, Z. M. 2003. The Qinghai-Tibet Plateau uplift and its impact on Tethys flora (in Chinese with English abstract). - Adv. Earth Sci. 18: 852-862.

Tang, Y. C. 2000. On the affinities and the role of the Chinese flora (in Chinese with English abstract). - Acta Bot. Yunnanica 22: 1-26.

Terradas, J. 1999. Holm oak and holm oak forests: an introduction. - In: Rodà, F., Retana, J., Gracia, C. A. et al. (eds.), Ecology of Mediterranean evergreen oak forests. Springer, pp. 3-14. 
Triat-Laval, H. 1979. Histoire de la forêt Provençale depuis 15000 ans d'après 1 'analyse pollinique. - For. Mediterranean 1: 19-24.

Yang, Q. Z. 1990. The characteristics and classification of sclerophyllous oaks in the Himalayan region of China (in Chinese with English abstract). - Acta Phytoecol. Geobot. Sin. 14: 197-211.

Yu, Y., Cao, M. and Liu, W. S. 2003. Diversity of tree species of subalpine coniferous forests and Quercus sclerophyllous forests in Northwest Yunnan (in Chinese with English abstract). - J. Mount. Sci. 21: 568-575.

Zhang, S. B., Zhou, Z. K., Hu, H. et al. 2005. Photosynthetic performances of Quercus pannosa vary with altitude in the
Hengduan Mountains, southwest China. - For. Ecol. Manage. 212: 291-301.

Zhou, Z. K. 1993. Geographic distribution of Quercus from China (in Chinese with English abstract). - J. Grad. School Acad. Sin. 10: 95-108.

Zhou, Z. K. 1999. Fossils of the Fagaceae and their implications in systematics and biogeography (in Chinese with English abstract). - Acta Phytotaxonomica Sin. 37: 369-385.

Zhou, Z. K., Pu, C. X. and Chen, W. Y. 2003. Relationships between the distributions of Quercus sect heterobalanus (Fagaceae) and uplift of Himalayas (in Chinese with English abstract). - Adv. Earth Sci. 18: 884-890. 